\title{
PENGUATAN OTONOMI GURU DI BAWAH TEKANAN DOMINASI PENGUASA DAERAH
}

\author{
Arif Rohman \\ Fakultas Ilmu Pendidikan Universitas Negeri Yogyakarta \\ email: arv_2013@yahoo.co.id
}

\begin{abstract}
Abstrak: Penelitian ini bertujuan menjelaskan penguatan otonomi guru di bawah dominasi penguasa daerah. Pendekatan penelitian adalah kualitatif fenomenologis dengan lokasi di Kabupaten Bantul. Subjek sebanyak 37 orang dipilih secara purposive. Pengumpulan data lewat angket terbuka, wawancara mendalam, dan kajian dokumen, serta trianggulasi melalui metode dan sumber, diskusi ahli, dan penjelasan banding. Analisis data dilakukan secara kualitatif fenomenologis. Temuan penelitian sebagai berikut. Pertama, penguatan otonomi menurut pandangan guru merupakan upaya menguatkan kualifikasi akademik dan kompetensi. Guru yang otonom adalah guru yang tidak terombang-ambing oleh kepentingan politik. Puncak penguatan otonomi guru adalah diperolehnya karakter dan kedaulatan. Kedua, terdapat politisasi guru oleh penguasa daerah melalui 'praktik terselubung' untuk 'meraih dukungan' dan berujung pada bargaining politik dan sharing kekuasaan. Ketiga, ada dua bentuk politik dominasi penguasa terhadap guru, yaitu melalui 'politik kooptasi' dan 'politik pengambilan hati'. Keempat, politik kooptasi berimplikasi negatif pada melemahnya sikap kritis guru, sedangkan politik pengambilan hati berimplikasi positif pada meningkatnya jumlah guru dalam studi lanjut dan meningkatnya kesejahteraan guru.
\end{abstract}

Kata Kunci: otonomi guru, politisasi, dan penguasa dominan

\section{STRENGTHENING THE TEACHER AUTONOMY UNDERTHE PRESSURE OF THE LOCAL AUTHORITY DOMINATION}

\begin{abstract}
This study was aimedtoexplainthe strengthening ofthe teacherautonomyunder the pressure of the local authority domination. This study was conducted in Bantul Regency usingthe phenomenological qualitative approach. The subjects consistedof 37people chosenthroughthe purposive sampling technique. The data were collected through open-ended questionnaires, in-depth interviews, and documentation. The triangulation was conducted through method and source triangulation, expert discussion, and comparative explanation. The data were analyzed using the phenomenological qualitative data analysis. The research findings were: First, in teachers' view, strengtheningthe autonomy was an effort to improve theacademic qualificationandcompetence.Autonomous teachers were those who were not easily influenced by political interest. The top of the strengthening of the autonomy was that teachers obtained character and freedom. Second, teachers were politicized by the local authority through disguised practices to gain support, and this resulted in political bargaining and political sharing. Third, there were two forms of the authority domination on teachers, that is, 'cooptation politics' and 'persuasion politics'. Fourth, cooptation politics had a negative implication the weakening of teachers' critical attitudes, while persuasion politicshad positive implication on the increasing number of teachers who took further study and on the improvement of teachers' welfare.
\end{abstract}

Keywords: teacherautonomy, politization, anddominant authority

\section{PENDAHULUAN}

Guru merupakan sosok manusia yang dapat 'digugu' (ditaati) dan 'ditiru' (diikuti). Guru adalah sosok yang ditaati karena ucapannya memuat nasihat kebenaran (truthfulness) dan kejujuran (fairness) menuju jalan hidup se- lamat. Guru juga sosok yang diikuti karena tingkah-lakunya mengandung keteladanan akhlak (moral) dan karakter baik (good character). Citra diri positif yang demikian merupakan label yang telah disematkan masyarakat tradisional kepada guru selama ratusan tahun. Oleh 
karena itu, guru dianggap mayoritas masyarakat sebagai manusia dengan karakter terpuji yang terpancar dalam bentuk kedalaman ilmu, kebenaran tutur kata, kesantunan perilaku, kesahajaan penampilan, keramahan tegur sapa, kesalehan beribadah, dan ketulusan pengabdiannya. Sosok guru dengan karakter terpuji tersebut pada gilirannya memberi pengaruh positif bagi masyarakat sekelilingnya dalam rangka membangun kemajuan peradaban umat manusia.

Sebagai sosok dengan karakter terpuji, peran guru menjadi amat strategis dalam proses transformasi sosial di masyarakat. Hal ini sejalan dengan pendapat Meyer (Hadisusanto, Sidharta, dan Siswoyo: 1995) bahwa guru berperan dalam "a process leading to the enlightenment of mankind". Begitu juga Joni (1991) menyebut guru berperan dalam mengembangkan sumberdaya manusia yang dapat menentukan kelestarian dan kejayaan kehidupan bangsa. Oleh karena itu, guru sering terlibat bersama masyarakat dalam menyelesaikan aneka persoalan kemasyarakatan. Mereka terlibat bersama dalam perjuangan membebaskan masyarakat dari aneka belenggu dan masalah, termasuk di dalamnya masalah politik. Koesoema (2009) menyebutkan bahwa perjuangan guru bersama masyarakat dalam politik dipahami dalam dua telaah, yaitu telaah historis-faktual, dan telaah normatif-idealis. Telaah historis-faktual merupakan telaah dengan mendasarkan pada data sejarah, sedangkan telaah normatif-idealis merupakan telaah dengan mendasarkan pada konsep, pemahaman, dan nilai yang dipahami guru sebagai pelaku perubahan dalam memandang dunia di mana mereka hidup.

Keterlibatan guru bersama masyarakat dalam mengatasi aneka masalah sosial politik merupakan cerminan relasi antara guru dan masyarakat. Relasi antarkeduanya beserta dinamikanya terjadi seiring dengan intensitas relasi yang mereka bangun. Melalui keterlibatan bersama masyarakat, menjadikan guru sebagai bagian tak terpisahkan dalam interaksi antarkelompok sosial politik masyarakat.

Spring (1993) berpendapat bahwa dalam proses interaksi antarkelompok masyarakat un- tuk mewujudkan cita-cita bersama, guru menjadi bagian penting di dalamnya. Guru menjadi bagian tak terpisahkan dalam interaksi bersama dengan aneka kelompok kepentingan dan kelompok politik dalam masyarakat. Kelompok kepentingan merupakan kumpulan orang yang berusaha mempengaruhi kebijakan publik yang dirumuskan dan diimplementasikan oleh pemerintah. Kelompok kepentingan dibedakan menjadi dua, yaitu kelompok kepentingan politis (political interest groups) dan kelompok kepentingan nonpolitis (non-political interest groups). Kelompok kepentingan politis berorientasi pada usaha meraih jabatan politik dalam pemerintahan. Sebaliknya, kelompok kepentingan nonpolitis tidak berorentasi pada usaha meraih jabatan politik dalam pemerintahan.

Secara normatif, guru tidak termasuk jenis kelompok pertama, tetapi termasuk jenis kelompok kedua. Hal ini disebabkan guru relatif tidak bermotivasi untuk meraih jabatan politik dalam pemerintahan. Guru lebih memilih tugas mendidik dan mengajar anak-anak di sekolah. Dengan demikian, guru lebih bermotivasi mencerdaskan kehidupan bangsa.

Namun, apakah realitasnya demikian? Inilah yang menjadi pertanyaan penting. Beberapa kasus secara tentatif mengindikasikan hal yang berbeda. Nuansa orientasi untuk kepentingan politik dalam tindakan guru nampak terindikasi. Fenomena demonstrasi guru terhadap kekuasaan politik akhir-akhir ini menunjukkan hal tersebut, seperti demonstrasi lima puluh ribu guru 'mengepung' Istana Presiden Abdurahman Wahid (Media Indonesia, 19 April 2000). Begitu juga pada era Presiden Susilo Bambang Yudoyono terjadi demonstrasi dua puluh delapan ribu guru menolak penghapusan Direktorat Jenderal Peningkatan Mutu Pendidikan dan Tenaga Kependidikan (Kompas, 12 Mei 2010). Bahkan, tahun 2002, demonstrasi guru di Kabupaten Kampar Provinsi Riau berhasil melengserkan Bupati Jefry Noer dari kursi kekuasaannya, atau demonstrasi guru di Kabupaten Lombok Timur yang berhasil menonaktifkan kekuasaan Bupati Ali Dahlan melalui aklamasi Sidang Paripurna DPRD setempat (Pantoro, 2010). Oleh karena itu, pertanyaannya adalah mengapa hal tersebut 
dapat terjadi demikian? Bagaimana relasi guru dengan kekuasaan politik? Bagaimana usaha guru dalam penguatan otonominya?

Secara teoretik, guru dituntut dapat mengembangkan otonomi menuju profesionalitas dalam mendidik dan mengajar anak. Profesi guru sebagai profesi penting dan strategis yang memiliki tugas memajukan peradaban umat manusia. Oleh karena itu, guru sangat memerlukan otonomi yang merujuk pada kedaulatan (sovereignty). Dengan otonomi, guru dapat benar-benar bekerja profesional tanpa dipengaruhi pertimbangan dari luar. Hal ini tercermin pada Sumpah Guru Nomor 8, yang berbunyi, "Sebagai guru Indonesia saya bersumpah, akan berusaha secara sungguh-sungguh untuk melaksanakan tugas guru tanpa dipengaruhi pertimbangan unsur-unsur di luar kependidikan" (PGRI, 2008).

Sumarno (2013) mengemukakan bahwa konsep otonomi lebih tepat dipakai self aware autonomy yang berdasar pada penghargaan tinggi atas sifat dasar manusia, yang disebut pula reflexivity. Otonomi yang berdasar pada penghargaan tinggi sifat dasar manusia atau otonomi reflektif akan memiliki akibat lebih baik, karena otonomi macam ini didukung dengan analisis dan pertimbangan yang matang. Sebaliknya otonomi dalam arti hanya penekanan kebebasan membuat keputusan dapat mengarah pada disorientasi atau bahkan anarkhi. Hal ini berlaku bagi kehidupan individual (seperti konsep Kohlberg tentang moral autonomy), kolektif, maupun komunal. Salah satu indikator dari ketepatan dan kualitas otonomi adalah kedaulatan (soverignty), dalam arti tidak ada kekuatan luar yang menekan atau memaksakan kehendak. Namun, setiap entitas yang berdaulat senantiasa arif bijaksana di dalam setiap keputusan dan tindakannya.

Konsep otonomi di atas amat relevan diterapkan pada diri guru. Profesi guru sebagai profesi penting dan strategis yang memiliki tugas untuk memajukan peradaban umat manusia, maka amat memerlukan kedaulatan (soverignty) yang didukung dengan analisis dan pertimbangan matang. Dengan otonomi, profesi guru diharapkan benar-benar dapat lebih berdaulat dalam melaksanakan tugas-tugas profesi yang profesional tanpa dipengaruhi pertimbangan dari luar. Berdasarkan argumen tersebut, maka otonomi guru dimaknai sebagai kemandirian guru dalam melakukan banyak hal yang terkait dengan profesi guru. Dengan demikian otonomi guru merupakan otonomi profesi sebagai seorang guru yang profesional. Sebagai seorang guru profesional, ia dituntut untuk sungguhsungguh meningkatkan keharusan profesional.

Otonomi guru ditunjukkan oleh kemampuannya untuk menentukan sikap dan perilakunya sendiri tanpa harus ada campur tangan orang lain, tetapi juga harus berani mempertanggungjawabkan perilaku pilihannya. Sepanjang menyangkut profesi guru, perilaku pilihannya harus dapat dipertanggungjawabkan secara filosofis, teoretis-edukatif, dan sosiokultural kepada anak didik, orang tua, sekolah, pemerintah, dan masyarakat luas.

Otonomi guru merupakan otonomi profesi yang dimiliki guru dalam menjalankan tugas-tugas profesi yang profesional, meliputi tugas mendidik, mengajar, membimbing, melatih, menilai dan mengevaluasi peserta didik di sekolah. Otonomi profesi guru berdasarkan landasan hukum dengan prinsip-prinsip profesionalitas sebagaimana tertuang di dalam UndangUndang RI Nomor 14 tahun 2005 tentang Guru dan Dosen pada pasal 7 ayat (1) yaitu memiliki tanggung jawab atas pelaksanaan tugas keprofesionalan, antara lain: (1) merencanakan, melaksanakan, menilai, dan mengevaluasi proses pembelajaran yang bermutu; dan (2) meningkatkan dan mengembangkan kualifikasi akademik dan kompetensi secara berkelanjutan sejalan dengan perkembangan ilmu pengetahuan, teknologi, dan seni.

Pada bagian lain, guru dengan peran dan tanggung jawabnya terhadap aneka problem masyarakat menuju kemajuannya, menjadikan mereka tidak dapat menghindar dari relasi dan interaksi dengan aneka kelompok kepentingan (interest group) masyarakat. Bahkan, menurut Apple (Tilaar, 2003), guru dan pendidikan memiliki relasi esensial dengan kekuasaan. Kekuasaan negara mencakup segenap pengaturan kehidupan masyarakat, termasuk kehidupan 
pendidikan dan guru. Penguasa memiliki kepentingan terhadap guru, sebaliknya guru juga menaruh harapan besar atas perhatian penguasa.

Relasi antara guru dan penguasa secara normal dapat berlangsung secara fungsionalsimbiotik. Artinya keduanya memiliki relasi saling menguntungkan. Namun, pada banyak kasus tidak selamanya bisa berlangsung positif, akan tetapi negatif berupa pola relasi eksploitatif dan dominatif. Pola relasi negatif tersebut hanya menguntungkan satu pihak yaitu penguasa, sedangkan guru kurang diuntungkan bahkan ditindas hanya untuk melayani kepentingan kekuasaan.

Perspektif teori konflik, menjelaskan di dalam sistem sosial tidak selamanya terdapat keteraturan akan tetapi justru ketegangan dan pertentangan. Dalam kasus di atas, ketegangan dan pertentangan terjadi antara guru dengan penguasa. Proses ketegangan dan pertentangan melahirkan dominasi (domination), koersi (coercion), dan opresi (oppression). Baik guru dan penguasa memiliki otoritas berbeda, yang pada akhirnya menghasilkan pemisahan kutub kekuatan sosial yaitu subordinasi dan superordinasi (Ritzer, 1996).

Pola relasi pertentangan yang kurang seimbang tersebut, guru sering hanya dijadikan sebagai alat kepentingan kekuasaan. Banyak kasus di daerah berupa aneka praktik ketidakadilan penguasa daerah terhadap guru. Laporan Republika disebutkan, "Saat pelaksanaan pilkada, banyak kepala daerah main ancam guru akan dimutasi ke daerah terpencil atau diturunkan statusnya dari kepala sekolah menjadi guru bantu, seperti yang terjadi pada beberapa kabupaten dan kota" (Republika, 22 November 2011). Laksana (2011) mengemukakan bahwa praktik kekuasaan despotik yang diperagakan penguasa daerah terhadap guru melalui bentukbentuk mutation (pergeseran) dan demotion (penurunan) atas tugas-tugas kedinasan guru sudah sering terjadi.

Giroux dan Mc Laren (1989) menguatkan bahwa guru bersama warga sekolah dimanfaatkan oleh penguasa dominan dijadikan sebagai instrumen untuk mendukung the logic of domination and oppression. Lebih jauh guru dieksploitir sedemikian rupa untuk menanamkan watak kepatuhan warga terhadap kekuasaan. Inilah yang oleh Gramsci (Sugiono, 1999) guru dimanfaatkan oleh penguasa menjadi alat hegemoni. Dengan strategi ini, dua keuntungan dapat dipetik penguasa: (1) terwujudnya mentalitas kepatuhan warga atas dominasi penguasa; dan (2) tercapainya resiko minimal bila penguasa memakai alat birokrasi atau polisi untuk menguasai warga. Oleh karena itu, dengan dalih demi pembaharuan pendidikan, menurut Collins (1979) guru telah diarahkan dan dibentuk sedemikian rupa untuk menjadi alat efektif dalam melanggengkan kekuasaan dominan (rezim).

\section{METODE}

Pendekatan dalam penelitian ini adalah kualitatif fenomenologis. Metode ini dipilih karena memungkinkan peneliti membekali diri dengan teori dan hipotesis secara tentatif untuk dikembangkan di lapangan secara berkelanjutan berdasarkan temuan empirik. Pendekatan ini membolehkan peneliti dengan frames and system of interpretation memberikan makna lebih jauh dari empiri, juga memungkinkan peneliti bergerak dari sebagai alat untuk mengungkap intensionalitas subjek yang diteliti, yaitu guru dan penguasa daerah. Pendekatan kualitatif fenomenologis yang dipilih lebih berakar pada teori interpretif Michel Foucault dan Jürgen Habermas.

Penelitian dilakukan di kabupaten Bantul, propinsi Daerah Istimewa Yogyakarta, dengan subjek dipilih secara purposive yang berasal dari unsur kepala sekolah, guru, pengawas, ketua Kelompok Kerja Guru (KKG), kepala UPT Pengelola Pendidikan Dasar (PPD), pengurus organisasi serikat guru (PGRI dan PGSI), pejabat pemerintah kabupaten Bantul, Pejabat Dinas Pendidikan Dasar, dan pimpinan Dewan Perwakilan Rakyat Daerah (DPRD) Bantul. Subjek yang berasal dari unsur kepala sekolah dan guru dibedakan dahulu secara cluster (negeri dan swasta) baru kemudian masing-masing dipilih secara purposive. Secara keseluruhan, subyek yang terpilih berjumlah 37 orang subjek. 
Penelitian dilakukan dengan lima langkah prosedural meliputi: tahap awal, tahap pengembangan rancangan, tahap pendalaman, tahap penyusunan, dan tahap akhir atau penyajian hasil. Pencarian data dilakukan melalui tiga cara: angket terbuka, wawancara mendalam, dan kajian dokumen. Angket terbuka berisi pertanyaan-pertanyaan tentang pendapat, persepsi, dan kesaksian subjek terpilih tentang otonomi guru dan dominasi kekuasaan, diberikan kepada subjek guru. Wawancara mendalam berisi pertanyaan-pertanyaan dialogis yang ditujukan kepada semua kelompok subjek, khusus guru hanya dipilih 10 orang yang diwawancarai dari 60 orang guru yang diberi angket. Wawancara dilakukan untuk menggali jenis data verbal tentang ide, pendapat, persepsi, dan kesaksian para subjek tentang otonomi guru dan dominasi kekuasaan. Wawancara juga dipakai sebagai pendalaman lebih jauh atas temuan dari data angket dan hasil kajian dokumen.

Adapun kajian dokumen dilakukan peneliti dengan cara pengumpulan dan pengkajian data politik dan data kepegawaian yang dimiliki oleh dinas pendidikan dasar dan kantor Sekretariat Daerah Pemerintah Kabupaten Bantul. Dengan demikian ketiga-tiganya, baik angket, wawancara, dan kajian dokumen, dipakai oleh peneliti secara komplementer atau saling melengkapi satu dengan yang lain. Peneliti meyakini bahwa tidak ada satu metode yang efektif dipakai untuk menggali semua jenis data yang berasal dari semu sumber data. Trianggulasi dipakai tiga jenis trianggulasi, yaitu metode dan sumber, trianggulasi diskusi ahli, dan trianggulasi rival explanations.

Adapun analisis datanya adalah kualitatif fenomenologis sebagaimana yang diusulkan oleh Creswell (2012), yaitu melalui langkahlangkah analisis: (1) data managing, (2) reading and memoing, (3) describing, (4) classifying, (5) interpreting, dan (6) visualizing.

\section{HASIL DAN PEMBAHASAN}

Bahwa penguatan otonomi guru menuju sosok profesional adalah upaya yang banyak dipengaruhi oleh dinamika politik di daerah. Pengaruh tersebut antara lain datang dari pe- jabat pemerintah daerah, pimpinan DPRD, dan pengurus PGRI. Masing-masing dari mereka memiliki kepentingan terhadap guru. Dari segi kepentingan pejabat daerah dan pimpinan DPRD, penguatan otonomi guru diarahkan kepada peningkatan kemampuan profesional guru demi mendukung pencapaian kemajuan masyarakat. Dari segi kepentingan pengurus PGRI, penguatan otonomi guru diarahkan kepada peningkatan kinerja guru yang lebih profesional untuk memajukan dunia pendidikan. Namun dari pihak individu guru, penguatan otonomi guru diarahkan untuk memenuhi kewajiban sebagaimana yang dituntut oleh undang-undang guru, yaitu peningkatan kualifikasi akademik dan kompetensi guru. Peningkatan kualifikasi dan kompetensi guru tersebut pada ujungnya adalah untuk kemajuan pendidikan.

Penguatan otonomi menurut guru merupakan tuntutan zaman seiring dengan peningkatan perubahan kehidupan masyarakat. Penguatan otonomi guru amat berpengaruh pada perubahan sekolah dan pendidikan. Dalam pandangan guru, upaya menguatkan otonominya adalah sebuah kewajiban yang harus dijalankan sebagaimana ditekankan pemerintah dan diatur di dalam undang-undang. Salah satu dari guru menuturkan seperti berikut.

"Sudah menjadi kewajiban saya sebagai guru untuk meningkatan kemampuan agar semakin profesional. Pemerintah juga mewajibkan para guru untuk meningkatkan kemampuan mendidik dan mengajar anak-anak di sekolah. Bahkan, hal ini sudah diberlakukan di dalam undang-undang guru. Bagi saya, peningkatan kemampuan guru memang perlu, agar pendidikan bisa maju". (21/11/11/GN-SL).

Penuturan guru tersebut merupakan bentuk kesadarannya sebagai tanggung jawab atas status yang disandangnya. Kesadaran guru tersebut diarahkan untuk menjalankan amanat Undang-Undang RI Nomor 14 Tahun 2005 tentang Guru dan Dosen. Sebagaimana diatur oleh undang-undang tersebut, ada dua kewajiban yang harus dijalankan guru yaitu peningkatan kualifikasi akademik dan kompetensi keguruan. Ke- 
wajiban guru meningkatkan kualifikasi akademiknya untuk menempuh studi lanjut sampai ke taraf diploma IV atau sarjana S-1. Kewajiban guru meningkatkan kompetensi keguruannya berupa keharusan guru menguasai empat kompetensi yaitu: pedagogik, kepribadian, profesional, dan sosial. Hal ini sebagaimana dituturkan oleh salah satu guru sebagai berikut.

"Kewajiban guru adalah meningkatkan kompetensi pedagogoik kepribadian, sosial, dan profesional. Ini merupakan tuntutan yang sudah ditulis di dalam undang-undang guru. Namun untuk melaksanakan tugas tersebut, tentu tidak mudah bagi saya. Mengingat saya bekerja di lapisan pendidikan paling bawah dengan banyak keterbatasan yang menyulitkan”. (22/11/ 11/GN-WG).

Atas dasar kesadaran guru di atas, peningkatan kualifikasi akademik dan kompetensi guru dianggapnya sebagai bentuk realisasi dari otonomi. Otonomi yang dimiliki guru harus diwujudkan dalam praktik mendidik, mengajar, menilai, dan tugas-tugas lainnya di sekolah. Namun demikian, usaha-usaha yang dilakukan guru dalam rangka meningkatkan otonominya tersebut masih belum sepenuhnya berhasil.

Mayoritas guru memahami bahwa guru yang otonom adalah guru yang independen dan tidak terombang-ambing oleh kepentingan politik. Puncak pengembangan otonomi guru adalah diperolehnya jati diri, yaitu karakter dan kedaulatan diri. Guru PNS mengaku loyal pada aturan dan perintah atasan, namun relatif netral dari politik. Sementara guru non-PNS mengaku loyal pada pengabdian diri untuk kemajuan pendidikan, namun tidak netral dari politik. Para guru mengakui bahwa keterlibatan mereka dalam politik lebih bersifat pribadi sebagai warga negara dan lepas dari statusnya sebagai guru. Guru PNS melakukan politik praktis secara sembunyi-sembunyi yang mereka sebut 'main lewat belakang', sedangkan guru non-PNS lebih berani terang-terangan. Hal ini sebagaimana diungkapkan oleh satu guru sebagai berikut.

"Sebenarnya saya tahu, beberapa teman guru walapun dia PNS banyak yang melakukan kegiatan politik praktis. Tidak sedikit temanteman yang berstatus PNS ikut menjadi tim sukses salah satu calon pada Pemilukada. Mereka sembunyi-sembunyi, main lewat belakang, tidak terang-terangan". (26/05/12/ GS-AJ).

Bagi guru non-PNS, keteribatan dirinya dalam politik praktis merupakan hal yang tidak perlu ditutup-tutupi. Mereka lebih berani terang-terangan melakukan kampanye politik mendukung salah satu calon atau kandidat. Tindakan politik guru non-PNS umunya melalui tiga modus, yaitu: kontrak politik, demonstrasi, dan audiensi. Menurutnya, tindakan yang mereka lakukan tersebut sebagai strategi memperjuangkan nasib guru Non-PNS. Sebagaimana diungkapkan oleh guru non-PNS yang telah terpilih menjadi anggota DPRD sebagai berikut.

"Dulu saya bersama beberapa teman pengurus Persatuan Guru Swasta Indonesia atau PGSI, pernah diundang oleh salah satu calon Bupati. Dia mengundang kami untuk melakukan kontrak politik untuk mendukung dan membantu dia. Menurutku, ini tidak salah. Ini merupakan bagian dari strategi untuk memperjuangkan nasib guru swasta. Bahkan, kami sebelumnya harus mau menggerakkan demonstrasi dan juga audiensi ke pemerintah". (04/05/12/GS-SL).

Namun demikian, usaha terus-menerus yang dilakukan oleh guru dalam rangka memperkuat otonominya melalui peningkatan kualifikasi akademik dan kompetensinya tetap berjalan meskipun mereka mengakuinya hanya seadanya dan semampunya. Usaha guru dalam penguatan kualifikasi akademik ditempuh melalui studi lanjut ke jenjang pendidikan sarjana strata-1, bahkan beberapa di antaranya dapat meraih pascasarjana strata-2 dan strata-3. Mereka berusaha memanfaatkan peluang mendapatkan bantuan studi lanjut yang ditawarkan pemerintah untuk menutupi kebutuhan biaya dalam meraih sarjana strata-1. Beberapa di antara mereka rela mengajukan pinjaman kepada koperasi sekolah dan lembaga keuangan perbankan.

Secara umum, usaha guru dalam meningkatkan kompetensi pedagogik diupayakan dengan melakukan perbaikan perancangan pem- 
belajaran efektif, pemilihan bahan ajar yang sesuai dengan karakteristik anak, peningkatan memahami teori-teori pembelajaran dan berlatih menerapkannya, pemilihan metode mengajar yang efektif, penggunaan metode mengajar yang bervariasi, pembuatan kreasi sendiri media pembelajaran dengan bahan dasar barang bekas. Selain itu, juga penyediaan lingkungan belajar yang kondusif antara lain dengan mendesain ulang secara periodik tata ruang kelas yang tidak membosankan siswa, penambahan pembelajaran secara remidial bagi siswa yang lamban belajar, dan penambahan komputer sebagai media pembelajaran.

Peningkatan kompetensi pedagogik tersebut mereka lakukan melalui usaha mandiri dan usaha kelompok dalam forum Kelompok Kerja Guru (KKG), mengikuti diklat dan bimbingan teknis (bintek) yang diselenggarakan dinas pendidikan dan LPMP, ada pula yang melalui kegiatan lokakarya di sekolah. Usaha yang disebut terakhir ini relatif jarang dilakukan guru karena kendala minimnya pengalaman manajemen dan sulitnya tenaga ahli. Hanya beberapa sekolah di perkotaan yang sering melakukannya.

Usaha guru dalam meningkatkan kompetensi kepribadian diupayakan dengan memahami secara tepat tentang usaha pengembangan kompetensi kepribadian di atas, antara lain mereka berupaya melakukan meningkatkan pemahaman dan pengamalan ajaran agama dalam kehidupan sehari-hari, menjadikan agama sebagai landasan akhlak mulia, meningkatkan sikap arif, bijaksana, dan berwibawa, sekuat tenaga berperilaku disiplin dalam datang mengajar dan pulang tepat waktu, dan berusaha menjadikan diri sebagai contoh bagi peserta didik dalam penampilan, tutur kata, dan sopan santun. Semua itu, sebagian besar dilakukan guru secara individual dalam praktik mandiri, ataupun melalui kerja kelompok dalam diskusi pengembangan di KKG, dan melalui bimbingan kepala sekolah.

usaha guru dalam meningkatkan kompetensi sosial diupayakan dengan memahami secara tepat tentang usaha pengembangan kompetensi sosial di atas, antara lain mereka ber- upaya melakukan peningkatan jalinan kerjasama yang baik dengan semua warga sekolah sehingga tercipta keharmonisan, peningkatan komunikasi yang akrab antarsesama guru dan dengan kepala sekolah, peningkatan cara berkomunikasi yang baik dengan orang tua/wali siswa, meningkatkan jalinan kerjasama dengan orang tua demi perkembangan siswa, dan menyelesaikan aneka masalah dalam kehidupan bersama di sekolah. Semua itu sebagian besar dilakukan secara praktik kolektif dan bimbingan kepala sekolah.

Adapun usaha guru dalam meningkatkan kompetensi profesional diupayakan dengan memahami secara tepat tentang usaha pengembangan kompetensi profesional di atas, antara lain mereka berupaya melakukan peningkatan pemahaman materi pendidikan secara terus-menerus, menempuh studi lanjut ke jenjang lebih tinggi sehingga penguasaan ilmu meningkat, memanfaatkan TIK untuk menambah penguasaan materi. Semua itu sebagian besar dilakukan secara mandiri dan sebagian lagi dilakukan dengan berdiskusi di dalam KKG, lokakarya sekolah, diklat, bintek, dan seminar yang diikutinya.

Semua usaha guru tersebut di atas didukungan oleh kepala sekolah melalui pemberian ijin dan nasehat, pun pula oleh pemerintah daerah melalui pemberian dukungan dana program peningkatan mutu guru. Pada tahun 2012 Dinas Pendidikan Dasar Kabupaten Bantul telah menjalankan tujuh program kebijakan tersebut, meliputi: (1) program studi lanjut ke jenjang pendidikan lebih tinggi; (2) program pemberdayaan KKG; (3) program pelaksanaan UKG dan sertifikasi guru; (4) program perlombaan inovasi dan kreativitas guru; (5) program peningkatan keaktifan guru dalam KKG, (6) program pendidikan dan latihan (diklat); dan (6) program peningkatan kesejahteraan guru.

Beberapa data temuan menunjukkan bahwa seiring dengan usaha para guru meningkatkan kompetensi dirinya menuju sosok guru profesional. Selain itu, terdapat pula peningkatan dari tahun ke tahun kepangkatan guru, pun pula peningkatan yang berhasil diraih guru sebagai guru berprestasi dari tahun ke tahun, serta peningkatan secara relatif jumlah guru yang lulus 
dalam uji sertifikasi guru, meskipun persyaratan kelulusan sudah semakin diperketat dari tahun ke tahun, baik melalui portofolio maupun melalui PLPG (Pendidikan dan Latihan Profesi Guru).

Pada bagian lain, usaha untuk menghambat otonomi guru oleh pihak lain diakui oleh banyak informan sangat kuat terjadi. Banyak informan yang menuturkan adanya dominasi politik terhadap guru yang dilakukan oleh penguasa daerah di lokasi penelitian. Menurutnya, banyak guru yang ditarik oleh penguasa daerah masuk ke dalam politik praktis dan terlibat dalam kampanye untuk mendukung calon tertentu.

"Saya katakan memang ada, yang namanya usaha menarik guru ke arah politik itu ada. Terutama guru-guru swasta amat rentan menjadi aset politik. Guru-guru negeri pun ditarik ke politik, padahal mereka itu PNS, Aturannya harus netral tidak boleh berpolitik. Tapi saya tahu, banyak dari PNS yang berkampanye untuk mendukung calon dari istri penguasa. Yaa... tentu saja di muka dia lurus-lurus saja berpura-pura netral, tapi di belakang dia tidak begitu”. (04/05/12/DP-SS).

Meskipun dibantah oleh penguasa melalui Sekda tentang adanya politik dominasi terhadap otonomi guru, namun banyak pengakuan dan bukti yang memperkuat adanya dominasi penguasa daerah atas otonomi guru. Usaha politik dominasi penguasa atas otonomi guru adalah melalui mobilisasi. Menurut sekretaris tim sukses pencalonan istri penguasa menjadi Bupati dinyatakan: "Mobilisasi PNS itu pasti, mengingat posisi mereka yang strategis di masyarakat. Selagi bisa dimanfaatkan, kenapa tidak..?" (29/01/13/TS-Ar).

Proses mobilisasi guru dilakukan oleh penguasa daerah secara sistematis dalam bentuk 'praktik terselubung' atau praktik secara sembunyi-sembunyi agar tidak diketahui oleh pihak lain. Praktik tersebut mereka namakan praktik 'di belakang layar' atau 'main belakang'. Dari luar seolah tidak terjadi apa pun, pihak yang akan mempermasalahkannya sulit menemukan buktinya, akan tetapi secara terselubung terjadi political bargaining. Proses mobilisasi guru mereka pahami sebagai bentuk 'politisasi guru' yang ditujukan oleh penguasa daerah untuk 'meraih dukungan' dari masyarakat luas melalui guru sebagai bentuk legitimasi karena guru merupakan massa terdidik yang diyakini memiliki 'posisi strategis'.

Tugas guru dalam melaksanakan 'pekerjaan politik' yang telah sukses bukan tanpa imbalan, karena terbukti hasilnya memuaskan sang penguasa. Hasil Pemilukada tahun 2010, calon dari penguasa meemperoleh kemenangan secara telak (68\%). Bahkan sampai awal tahun 2013, kemenangan tersebut dapat diterima banyak pihak dan tidak ada protes atau gejolak politik atas hasil tersebut. Atas jerih payah para guru tersebut, penguasa daerah memberikan 'imbalan jasa politik' dalam bentuk 'jabatan politik' ketika usai pemenangan pemilukada. Menurut sumber yang kebetulan sebagai sekretaris Tim Pemenangan istri bupati (Bupati yang sekarang), bahwa atas keberhasilannya dalam pemilukada tahun 2010 beberapa guru memperoleh 'hadiah' dengan diangkat menjadi pejabat daerah. Hal ini sejalan dengan penuturan sumber lain yang menyebutkan banyaknya pejabat dinas pendidikan yang baru diangkat yang berasal dari guru.

"Ibu Sekretaris Dinas Pendidikan Dasar itu dulunya guru, Bapak Kasi Kurikulum dulunya guru, Kabid SD dulunya juga guru, bahkan Bapak Kepala Dinas juga sebelumnya jadi guru SD di Dlingo, dan masih banyak lagi, yang dulunya berasal dari guru". (29/ 12/12/PG-SD).

Data hasil penelusuran dokumen yang ada di Kantor Badan Kepegawaian Daerah tahun 2012 diperoleh data tentang nama-nama pejabat di lingkungan pemerintah Kabupaten Bantul yang berasal dari guru. Terdpat 11 (sebelas) orang pejabat yang diangkat Bupati Bantul untuk menduduki aneka bidang di kantor birokrasi di lingkungan Kabupaten Bantul, yaitu: (1) Kepala Dinas Pendidikan Dasar; (2) Kepala Dinas Pendidikan Menengah dan Nonformal; (3) Kepala Kantor Inspekorat Daerah; (4) Kepala Kantor Pemuda dan Olahraga; (5) Kepala Bidang Menengah Umum Dinas Pendidikan Menengah 
dan Nonformal; (6) Kepala Bidang Menengah Kejuruan Dinas Pendidikan Menengah dan Nonformal; (7) Kepala Bina Program Dinas Pendidikan Dasar; (8) Sekteratis Dinas Pendidikan Dasar; (9) Kepala Bidang Sekolah Dasar Dinas Pendidikan Dasar; (1) Kasi Kurikulum Sekolah Dasar Dinas Pendidikan Dasar; dan (11) Kasi Kurikulum SMA Dinas Pendidikan Menengah dan Nonformal.

\section{Pembahasan}

Berdasarkan pemaparan hasil penelitian di atas dapat diketahui bahwa penguatan otonomi guru menuju sosok profesional merupakan hal yang sangat urgen bagi kemajuan pendidikan. Semua pihak berkepentingan terhadap penguatan otonomi guru, mulai dari pejabat pemerintah daerah, pimpinan DPRD, pengurus PGRI, maupun oleh guru itu sendiri. Dengan demikian, upaya peningkatan otonomi guru menjadi amat politis. Hal tersebut sejalan dengan pendapat Spring (1993:3) yang menyebutkan bahwa guru merupakan sosok komunitas penting yang menjadi bagian dari kelompok kepentingan politik yang saling berinteraksi untuk mewujudkan cita-cita masyarakat. Guru menjadi bagian penting di dalamnya sehingga perubahan kebijakan apa pun yang menyangkut guru selalu berimplikasi politis.

Dinamika politik yang ikut mempengaruhi upaya penguatan otonomi guru seyogyanya tidak menggiring guru ke arah kemerosotan kemandirian guru. Hal ini secara relatif telah diupayakan oleh para guru dengan menemukan kedaulatannya. Oleh karena mayoritas guru memahami bahwa guru yang otonom adalah guru yang independen dan tidak terombangambing oleh kepentingan politik, maka puncak pengembangan otonomi guru adalah diperolehnya jati diri yaitu karakter dan kedaulatan diri. Fenomena ini diistilahkan oleh Sumarno (2013: 10) dengan konsep self aware autonomy yang menjurus pada soverignty, yaitu tidak ada kekuatan luar yang menekan atau memaksakan kehendak guru.

Kesadaran para guru dalam memahami upaya penguatan otonominya adalah upaya memenuhi kewajiban sebagaimana yang dituntut oleh undang-undang guru. Penguatan otonomi guru sebagaimana dituntut oleh undang-undang guru adalah berbentuk peningkatan kualifikasi akademik dan kompetensi guru. Peningkatan kualifikasi akademik dan kompetensi guru tersebut pada ujungnya adalah untuk kemajuan pendidikan. Penguatan otonomi menurut guru merupakan bagian dari tuntutan zaman seiring dengan peningkatan perubahan kehidupan masyarakat demi memajukan sekolah dan dunia pendidikan.

Kesadaran guru di atas merupakan bentuk kesadaran yang dibenarkan secara yuridis. Sejak tahun 2005 pemerintah pusat telah memberlakukan Undang-Undang RI Nomor 14 tahun 2005 tentang Guru dan Dosen yang mewajibkan seluruh guru di Indonesia memiliki kualifikasi akademik dan kompetensi keguruan. Kewajiban guru meningkatkan kualifikasi akademiknya adalah menempuh studi lanjut sampai ke taraf diploma IV atau sarjana S-1. Kewajiban guru meningkatkan kompetensi keguruan merupakan keharusan guru untuk menguasai empat kompetensi: pedagogik, kepribadian, sosial, dan profesional.

Usaha guru dalam meningkatkan kualifikasi akademik dan kompetensinya di atas dipahami guru sebagai bentuk realisasi dari otonominya, yang ujungnya harus terbukti dalam praktik mendidik, mengajar, menilai, dan tugastugas lainnya di sekolah. Dengan ukuran ini, maka usaha-usaha yang dilakukan guru dalam rangka meningkatkan otonominya tersebut dianggap masih belum sepenuhnya berhasil.

Pemaparan hasil penelitian mengenai usaha guru dalam meningkatkan kualifikasi akademik menunjukkan hasil positif. Usaha terus-menerus yang dilakukan oleh guru dalam rangka memperkuat otonominya melalui peningkatan kualifikasi akademik ditempuh melalui studi lanjut ke jenjang pendidikan sarjana strata-1, bahkan beberapa diantara mereka dapat meraih pascasarjana strata-2 dan strata-3. Upaya gigih para guru ini merupakan bentuk kesungguhan (seriousness) mereka dalam mencapai kualifikasi akademik yang dipersyaratkan oleh undang-undang. 
Tabel 1. Usaha dan Bentuk Kegiatan Peningkatan Kompetensi Guru

\begin{tabular}{|c|c|c|c|}
\hline No. & $\begin{array}{c}\text { Jenis } \\
\text { Kompetensi }\end{array}$ & Deskripsi usaha Peningkatan Kompetensi & Bentuk Kegiatan \\
\hline 1. & Pedagogik & $\begin{array}{l}\text { - Perbaikan perencanaan pembelajaran } \\
\text { - Pemilihan bahan ajar yang relevan dengan kebutuhan } \\
\text { anak } \\
\text { - Peningkatan pemahaman teori dan praktik } \\
\text { pembelajaran } \\
\text { - Perbaikan metode dan media pembelajaran } \\
\text { - Perbaikan lingkungan belajar secara periodic } \\
\text { - Peningkatan pembelajaran remidial }\end{array}$ & $\begin{array}{l}\text { - Usaha mandiri } \\
\text { - Diskusi dan lokakarya } \\
\text { di KKG } \\
\text { - Lokakarya di sekolah } \\
\text { - Mengikuti dilkat oleh } \\
\text { Dinas }\end{array}$ \\
\hline 2. & Kepribadian & $\begin{array}{l}\text { - Peningkatan pemahaman dan pengalaman agama } \\
\text { - Peningkatan sikap bijaksana dan wibawa } \\
\text { - Peningkatan perilaku disiplin } \\
\text { - Perwujudan praktik keteladanan diri bagi siswa dalam } \\
\text { penampilan, perkataan, dan perbuatan }\end{array}$ & $\begin{array}{l}\text { - Usaha mandiri } \\
\text { - Diskusi dan lokakarya } \\
\text { di KKG } \\
\text { - Lokakarya oleh sekolah } \\
\text { - Bimbingan kepala } \\
\text { sekolah }\end{array}$ \\
\hline 3. & Sosial & $\begin{array}{l}\text { - Peningkatan kerjasama harmonis dengan semua } \\
\text { warga sekolah } \\
\text { - Peningkatan komunikasi akrab dengan sesame guru, } \\
\text { kepala sekolah, dan orang tua siswa. } \\
\text { - Diskusi dengan orang tua tentang perkembagan anak } \\
\text { - Penyelesaian aneka masalah kehidupan bersama di } \\
\text { sekolah }\end{array}$ & $\begin{array}{l}\text { - Kegiatan arisan } \\
\text { - Pengajian } \\
\text { - Paguyuban } \\
\text { - Bimbingan kepala } \\
\text { sekolah }\end{array}$ \\
\hline 4. & Professional & $\begin{array}{l}\text { - Peningkatan pemahaman materi pendidikan terus- } \\
\text { menerus } \\
\text { - Melakukan studi lanjut } \\
\text { - Pemanfaatan TIK untuk penguasaan materi } \\
\text { pembelajaran }\end{array}$ & $\begin{array}{l}\text { - Usaha mandiri } \\
\text { - Diskusi dan lokakarya } \\
\text { di KKG } \\
\text { - Lokakarya di sekolah } \\
\text { - Mengikuti dilkat dan } \\
\text { seminar } \\
\text { - Penugasan, saran, dan } \\
\text { briefing KS }\end{array}$ \\
\hline
\end{tabular}

\section{Tabel 2. Jabatan yang Pejabatnya Berasal dari Guru}

\begin{tabular}{ll}
\hline No. & Jabatan dengan Pejabatnya Berasal dari Guru \\
\hline 1. & Kepala Dinas Pendidikan Dasar \\
2. & Kepala Dinas Pendidikan Menengah dan Nonformal \\
3. & Kepala Kantor Inspekorat Daerah \\
4. & Kepala Kantor Pemuda dan Olahraga \\
5. & Kepala Bidang Menengah Umum Dinas Pendidikan Menengah dan Nonformal \\
6. & Kepala Bidang Menengah Kejuruan Dinas Pendidikan Menengah dan Nonformal \\
7. & Kepala Bina Program Dinas Pendidikan Dasar \\
8. & Sekteratis Dinas Pendidikan dasar \\
9. & Kepala Bidang Sekolah Dasar Dinas Pendidikan Dasar \\
10. & Kasi Kurikulum Sekolah Dasar Dinas Pendidikan Dasar \\
11 & Kasi Kurikulum SMA Dinas Pendidikan Menengah dan Nonformal \\
\hline (Sumber: BKD Bantul, 2012)
\end{tabular}

Usaha para guru dalam meningkatkan kompetensi mereka yang meliputi kompetensi pedagogik, kepribadian, sosial, dan profesional dilakukan melalui banyak cara dan bentuk ke- 
giatan. Secara ringkas, usaha dan bentuk kegiatan para guru dalam meningkatkan empat kompetensi dapat dilihat pada Tabel 1.

Tabel 1 dapat dimaknai bahwa adanya keragaman dan kegigihan para guru dalam meningkatkan kompetensinya sebagai pengejawantahan untuk memenuhi kewajiban perintah undang-undang guru. Empat kompetensi telah diupayakan guru secara individual maupun secara kolektif. Paling tinggi diupayakan ditingkatkan oleh guru adalah kompetensi pedagogik, sedang bentuk kegiatan yang paling banyak diupayakan oleh guru adalah kompetensi profesional.

Namun demikian, di tengah upaya guru memperkuat otonominya menuju pada sosok guru profesional, terdapat desakan politik yang menghimpit guru untuk masuk pada jebakan politik penguasa daerah. Politik dominasi yang dilakukan oleh penguasa daerah terhadap otonomi guru tersebut dikenal dengan 'politisasi guru', baik secara tersurat maupun tersirat untuk meraih 'kepentingan politik'. Praktik tersebut merupakan wujud dari political relation yang menjelma menjadi transaksi politik atau political bargaining yang berujung pada power sharing atau pembagian 'kue kekuasaan'.

Upaya sistematis penguasa daerah melalui 'politisasi guru' dilakukan untuk mewujudkan political bargaining dengan tujuan untuk 'meraih dukungan' dari masyarakat luas melalui guru sebagai bentuk legitimasi. Bila guru menolak atas upaya politisasi penguasa daerah, dapat berdampak pada karir kedinasan mereka. Hal ini sejalan dengan pendapat Laksana (2011:14) yang menyebutkan bahwa praktik kekuasaan despotik yang diperagakan penguasa daerah terhadap guru dapat berbentuk mutation (pergeseran) dan demotion (penurunan) atas tugas-tugas kedinasan guru. Begitu juga teori dari Giroux dan Mc Laren (1989: 174) memperkuat teorinya Laksana. Menurut Giroux dan Mc Laren, guru bersama warga sekolah dimanfaatkan oleh penguasa dominan dijadikan sebagai instrumen untuk mendukung the logic of domination and oppression.

Praktik politisasi guru oleh penguasa daerah tersebut dilihat dari teori yang dikemukakan Wong (2006:19), Wagman (2003:4), dan
Rubin \& Fausset (2005:3) disebut sebagai political relation yang berimplikasi pada political interest. Proses relasi politik untuk meraih kepentingan politik secara negatif dapat berujung pada political conflict, namun bila berlangsung secara positif akan berujung pada tawar-menawar politik atau political bargaining (Sack, 2002:19), yang oleh Davies (1997:86) disebut power sharing. Dengan demikian, kekuasaan yang dinikmati olehrezim penguasa daerah mendapatkan legitimasi.

Secara teoretik, ada lima jenis legitimasi, yaitu: tradisional, kualitas pribadi, formal-prosedural, instrumental, dan ideologi (Surbakti, 1992:25). Dalam hal kasus yang sedang diteliti ini, upaya penguasa daerah Bantul yang melakukan politisasi terhadap guru termasuk jenis legitimasi instrumental. Hal tersebut terjadi karena penguasa menjanjikan jaminan atau telah melaksanakan kesejahteraan material dan jabatan bagi guru-guru yang ada di wilayah Bantul.

Atas kesuksesan guru dalam melaksanakan tugas politik dari penguasa daerah, maka penguasa daerah memberikan 'imbalan jasa politik' dalam bentuk 'jabatan politik'. Ada 11 (sebelas) jabatan politik dalam birokrasi pemerintahan daerah yang pejabatnya diangkat dengan latar belakang sebagai guru.

\section{PENUTUP}

\section{Simpulan}

Kesimpulan yang dapat ditarik dari penelitian ini adalah bahwa penguatan otonomi menurut guru merupakan upaya meningkatkan kualifikasi akademik dan kompetensi. Hal ini dipahami oleh guru sebagai bentuk kewajiban mereka dalam memenuhi ketentuan undang-undang guru. Meskipun banyak tarikan dan desakan dari aneka kelompok kepentingan politik, upaya penguatan otonomi guru guna meningkatkan kualifikasi akademik dan kompetensinya dapat berjalan secara wajar meskipun kurang optimal. Peningkatan kualifikasi akademik dilakukan guru melalui peningkatan capaian jenjang pendidikannya menjadi sarjana strata-1, bahkan di antara mereka tidak sedikit yang berhasil meraih sarjana strata-2 dan strata-3. Para guru banyak yang memanfaatkan beasiswa dari 
pemerintah serta memanfaatkan lembaga jasa keuangan guna menutup kebutuhan keuangan dalam rangka meraih standar kualifikasi akademik tersebut.

Adapun peningkatan kompetensi ditempuh para guru melalui banyak usaha dan banyak cara dalam menguatkan kompetensinya. Ada empat kompetensi yang secara konsisten diupayakan untuk terus ditingkatkan oleh guru, yaitu kompetensi: pedagogik, sosial, kepribadian, dan profesional. Empat kompetensi yang telah diupayakan guru adalah upaya secara individual maupun secara kolektif. Paling tinggi diupayakan oleh guru untuk ditingkatkan adalah kompetensi pedagogik, sedang bentuk kegiatan yang paling banyak diupayakan oleh guru adalah kompetensi profesional.

Pemahaman guru tentang otonomi profesi merupakan kemandirian dan kedaulatan diri guru dalam bekerja mendidik, mengajar, dan tugas lainnya yang tujuannya adalah untuk memajukan sekolah dan dunia pendidikan. Guru yang otonom adalah guru yang tidak terombang-ambing oleh kepentingan politik. Mereka memiliki prinsip sendiri dalam memajukan sekolah dan dunia pendidikan. Oleh karena itu, puncak penguatan otonomi guru adalah diperolehnya karakter dan kedaulatan diri guru dalam dunia pendidikan.

Penguatan otonomi yang dilakukan guru dalam bentuk peningkatan kualifikasi akademik dan kompetensi, berjalan dengan penuh tekanan. Ketika guru berusaha meningkatkan kualifikasi akademik dan kompetensinya, terdapat desakan dan tekanan dari penguasa daerah kepada guru yang dikenal dengan politisasi guru. Proses politisasi oleh penguasa daerah kepada guru tersebut dilakukan melalui 'praktik terselubung' untuk 'meraih dukungan' dan berujung pada bargaining politik dan sharing kekuasaan. Semua itu merupakan usaha penguasa daerah dalam rangka memperoleh legitimasi kekuasaannya. Jenis legitimasi yang diperoleh oleh penguasa daerah adalah jenis legitimasi instrumental, karena penguasa menjanjikan jaminan atau membuktikan kesejahteraan material dan jabatan bagi guru-guru.
Imbalan yang diberikan oleh penguasa daerah kepada sebagian guru yang bersedia terlibat dalam program politiknya adalah diangkatnya sebelas pejabat birokrasi pemerintahan daerah yang berasal dari, meliputi: (1) Kepala Dinas Pendidikan Dasar; (2) Kepala Dinas Pendidikan Menengah dan Nonformal; (3) Kepala Kantor Inspekorat Daerah; (4) Kepala Kantor Pemuda dan Olahraga; (5) Kepala Bidang Menengah Umum Dinas Pendidikan Menengah dan Nonformal; (6) Kepala Bidang Menengah Kejuruan Dinas Pendidikan Menengah dan Nonformal; (7) Kepala Bina Program Dinas Pendidikan Dasar, (8) Sekteratis Dinas Pendidikan Dasar; (9) Kepala Bidang Sekolah Dasar Dinas Pendidikan Dasar; (1) Kasi Kurikulum Sekolah Dasar Dinas Pendidikan Dasar; dan (11) Kasi Kurikulum SMA Dinas Pendidikan Menengah dan Nonformal.

\section{Saran}

Terhadap hasil kesimpulan penelitian di atas, maka apat diberikan saran antara lain bahwa di masa yang akan guru harus lebih fokus pada tugas profesinya, yakni mendidik dan mengajar anak-anak di sekolah. Profesi guru bukanlah profesi politis yang berorientasi pada usaha meraih jabatan politik dalam pemerintahan. Profesi guru merupakan profesi dengan tanggung jawab mencerdaskan kehidupan bangsa. Hal ini perlu diperkuat dan diberikan arah yang pasti oleh organisasi profesi guru. Oleh karena itu, pihak penguasa daerah dan para politisi partai seyogyanya memahami posisi guru sebaik-baiknya, bukan sebaliknya menekan dan menarik guru untuk terlibat dalam politik praktis.

\section{UCAPAN TERIMA KASIH}

Ucapan terima kasih secara mendalam disampaikan kepada sponsor yang mendanai penelitian ini, narasumber, sejawat, dan berbagai pihak lain yang telah membantu penelitian dari awal hingga selesai. Semoga peran mereka semua diperhitungkan oleh Tuhan sebagai amal ibadah, amin. 


\section{DAFTAR PUSTAKA}

Collins, R. 1979. The Credentials Society: An Historical Sociology of Education and Stratification. New York: Academic Press.

Baedhowi. 2004. "Implementasi Kebijakan Otonomi Daerah Bidang Pendidikan: Studi Kasus di Kabupaten Kendal dan Surakarta". Disertasi. Jakarta: Universitas Indonesia.

Creswell, J. W. 2012. Qualitative Inquiry \& Research Design: Choosing among Five Approaches (Second Edition). London: Sage publications.

Giroux, H A. \& Mc Laren, PL. 1989. Critical Pedagogy, the state, and Cultural Struggle. New York: State University of New York.

Hadisusanto, D., Sidharto, S., \& Siswoyo, D. 1995. Pengantar Ilmu Pendidikan. Yogyakarta: FIP IKIP Yogyakarta.

Joni, T.R. 1991. "Pokok-pokok Pikiran mengenai Pendidikan Guru", dalam Conny R. Semiawan dan Soedijarto (ed) Mencari Strategi Pembangunan Pendidikan $\mathrm{Na}$ sional Menjelang Abad XXI. Jakarta: Gramedia.

Koesoema, D. 2009. "Guru sebagai Pelaku Transformasi Sosial". Makalah pada "Simposium Guru dalam perubahan sosial politik bangsa" Diselenggarakan di Aula SMU 6 Bulungan Jakarta, 15 Mei 2009, oleh Kerjasama MGMP Sejarah Provinsi DKI, Asosiasi Guru Sejarah Indonesia (AGSI), dan Institut Sejarah Sosial Indonesia (ISSI).

Laksana, S.D. 2011. "Kasihanilah Kepala Daerah”. Kedaulatan Rakyat. Harian, 24 November.

Pantoro, S. 2010. Demonstrasi Guru: Ada apa denganmu Guru. http: // setyopantoro. wordpress. com /2010/02/27. Diambil tanggal 9 Agustus 2010.

Ritzer, G. 1996. Sociological Theory: Fourth Edition. Maryland: The McGraw-Hill Companies

Rubin, J. \& Fausset, R. 21 November 2005. "Mayor Talks Tough to Push School Takeover". Los Angeles Times. Los Angeles.

Sack, J.L. 2002. "Hard Bargaining”. Education week, Volume 21, April.

Spring, J. 1993. Conflict of Interests: the Politics of American Education. New York: Longman.

Sugiono, M. 1999. Kritik Antonio Gramsci terhadap Pembangunan Dunia Ketiga. Yogyakarta: Pustaka Pelajar.

Sumarno. 2013. "Pendidikan untuk Pencerahan dan Kemandirian Bangsa". Pidato Dies Natalis Ke-49 Universitas Negeri Yogyakarta.

Surbakti, R. 1992. Memahami Ilmu Politik. Jakarta: Gramedia Widiasarana Indonesia.

Tilaar, HAR. 2003. Kekuasaan dan Pendidikan. Magelang: Indonesiatera.

Undang-Undang Republik Indonesia Nomor 14 Tahun 2005 tentang Guru dan Dosen. Jakarta.

Wagman, J. 2003. Power Brokers Play Role in Campaign for School Reform. St. Louis Post-Dispatch, July 20, 2003.

Wong, K.K. 2006. "The Political Dynamics of Mayoral Engagement in Public Education". Harvard Educational Review. Cambridge, Vol. 76, Iss. 2, 2006. 